\title{
The Mediating Effect of Firm Growth on the Relationship between Capital Structures and Value of Nonfinancial Firms listed at the Nairobi Securities Exchange (NSE)
}

\author{
Daniel Kon Ater, Dr. Sifunjo E. Kisaka, Dr. Cyrus Iraya, Dr. Mirie Mwangi \\ (Department of Finance and Accounting, School of Business, University of Nairobi)
}

\begin{abstract}
This study examines the mediating effect of firm growth on the relationship between capital structure and firm value among non-financial listed firms at the Nairobi Securities Exchange. Using hypotheses formulated from existing literature as per the gaps identified and tested. A target population of 36 non-financial firms at the NSE was selected. With a positivistic research philosophy complemented with descriptive research design such as mean, standard deviation, coefficient of variation, kurtosis and skewness and correlation analysis employed. The study used stepwise multiple regression analysis and in testing of hypothesized variables. Capital structure research being one of the most sensitive areas of corporate finance and decisionmaking because of the interrelationships with other components of financial decision. Findings pointed that firm growth has a significant mediating effect and is thus a critical tool that can be used by management when doing capital structures adjustments to ensure efficiency and optimality as firms grow. Policy makers are expected to adopt the results in monitoring listed firms' investment and funds are raised in the capital markets to reduce the delisting of companies from the NSE owing to non-performance.

Capital structure, financial performance, Firm growth, firm value, macroeconomic factors
\end{abstract}

\section{Introduction}

In both the emerging and in developed countries, limited research has been focused on the moderating effect of firm growth on the relationship between capital structure and the value of the firm. However, the among the few studies done there has emerged mixed outcomes concerning this relationship (Rajan \& Zingales, 1995; Rayan, 2008; and Akhtar \& Oliver, 2009; Campbell, Harveya, \& Karl, 2004). With the available literature pointing out there is a connection between firm growth, capital structure and firm value the mediating role of firm value has proved to be leading challenge among the academicians, professionals and the policy makers. Available studies from (Odongo, Thabang, \& Leonard, 2014, Murekefu \& Ouma, 2012 and Nyamao, Opera, Lumumba, Odondo, \& and Otieno, 2012) focus on the factors that determine the capital structure. These studies have all overlooked at the mediating effect firm growth on capital structure, and firm value for firms listed in the NSE capital market. It is expected that this study will equip firm management with adequate knowledge that can enable them plan properly when financing proposed projects. Besides the above the current study will enable them develop a plan on the sources of finances and thus ensure minimum risk in firm operations.

Firm growth as used in this study refers to the transition that happens in the firm's assets over time (Gopinath, 2012). Further, is the rate of change in a firm's wealth for the nonfinancial and financial assets, which are manned by a business at a given time. These assets are important in determining the value of the firm. In other disciplines, the growth of firms has been the focus of studies having a theoretical and an empirical debate. The present literature puts an emphasis on the firm growth with respect to the manufacturing sector. This is concerning the nonfinancial companies that were used in the study. Despite a number of studies that look into the factors determining a significant value through the application of firm growth in the emerging markets, most of them have directed their focus to company size and the economies of scale. According to Coad (2009), it is not easy to compare firms as they ascribe to different ideologies when it comes to defining business value. This results in different characteristics in every industry. Thus, one cannot establish a common characteristic in which the firms can be compared.

A study conducted in Dutch firms found that firm growth could be compared along the sector lines of an industry. For instance, service sector firms can be compared since they have similar characteristics (Audretsch, 2004). Firm growth in the current study is a change in total assets ratio over the period. Firm growth is an adage to the business activities of an organization over time. The increase in the company's asset value leads to an increase in the value of the firm (Penrose, 1959). Further, the amassed wealth is another aspect that the growth of the firm is viewed, which also leads to increase in value of the firm. Therefore, business that are growing have a window of opportunity if they use a well-drafted capital structure. This structure will enable them to become competitive in their industry. 
The firm value means the owned assets by a firm at a given period, which is equivalent to one year (Laitinen, 2002). It is an increase in the firm's property over the investment claims by the shareholders of the corporate. Further, the firm value is an investor's view of the company's success in relation to the stick prices (Birgham, \& Gapenski, 2006). Tobin Q describes the ratio of market capitalization of a firm in a given year. The equation used to measure this aspect is (Tobin $\mathrm{q}=(\mathrm{MVE}+\mathrm{BVD}) / \mathrm{BVA})$. The Tobin $\mathrm{Q}$ of these assets is calculated in the following way; assets linked to the stock price, which may be directly or indirectly quoted to include the continuity of growth but limit the rate (Penrose, 1959). Every focuses on maximizing its value through an evaluation of its structure of capital from a perspective of its influence on the value of the firm. The significant value is alternatively analyzed by the help of other perspectives off the balance sheet approach, which are the values of the company's owned assets. Zuraidah et al. (2012), Khan (2012), Ruan, 2011), Myers and Majluf, (1984) and Modigliani and Miller (1958) conducted a study in the year 2012, which reveals that the capital structure of a firm is related to the value of the firm in both positive and negative manner. The studies' findings also reveal that the business value is a linear function of a capital structure.

The corporate capital structure, a combination of debt and equity which the firm considered as it appropriates tools to enhance its activities which have been the subject of various studies in the development of corporate finance among other disciplines. The use of the capital structure is deemed to be one of the vitals strategies to mitigate the conflict of interest between management and the shareholders of the firm and therefore increases the firm value over the period (Berger \& Bonaccorsi, 2006). Among the theories of capital structure, pecking order theory contradicts the relationship between debt financing and the value of the firm, which state that there is a negative correlation between debt capital funding and substantial value (Donaldson, 1961, Myers, 1984, Myers \& Majluf, 1984). Many empirical pieces of evidence support capital structure as an important determinant of firm value in conjunction with many others factors, in which macroeconomic factors are among them (Rajan \& Zingles, 1995, Friend \& Hasbouck, 1998, Senarane, 1998, Myers \& Majluf, 1984). Therefore, it is crucial to examine the effects of the corporate capital structure using data from different markets on the value of the firm in various markets conditions to test the reliability and validity of these general assertions of business researchers.

\section{Objectives of the Study}

The principal objective of this study was to test empirically whether firm growth has a significant mediating effect the relationship between capital structure and firm value among companies listed at the Nairobi securities exchange (NSE). In assessing this the researcher had to study the different capital structures adopted by firms listed at the NSE and their growth trends besides their value over a five year period of between 20102014.

\section{Literature Review}

Numerous researches have exposed that the capital structure, growth of a firm and the value of the firm have a positive correlation. According to Mansoon \& Rauf (2013), a positive and notable relationship exists between the board size, the debt ratio and the remuneration of the managers in relation to the substance of the assets. Thus, debt financing is accompanied with a distinguishing benefit of tax deductions. When an additional debt fails to increase the risk of the financial distress, a company is likely to prefer raising its leverage. Consequently, the tax rate considered efficient will have a positive correlation to the debt ratio (Fama \& French, 2002). The structure of capital decisions that are arrived at by the managers are important when it comes to the joint debt and equity effect on the maximization of the firm value (Pandey, 2004). Velnampy et al. (2011) carried out a study that investigated the reorganization of the optimal capital structure of the corporates on the increase of the firm value. The outcome showed a significant relation of the debt and equity ratio to the firm value. This is an indication that forms are able to use debts in the formation of the corporate capital structure to increase to the highest level the value of the firm.

The growth and survival of a firm requires enough resources. However, the financing of these resources is limited. Thus, the application of these resources should be in a manner that establishes a proper value for the firm share value to both the providers and the resource users. Additionally, owing to the outcome of the pragmatic studies, the decisions of management on the capital structure are influenced by the growth rate of the firm (Hackbarth, Jianjun, \& Morellec, 2006, Antoniou, Guney, \& Paudyal, 2008; (Mokhova \& Zinecker, 2014).

In view of these, managers ought to focus on optimizing the capital structure in relation to the trade-off theory which is due to the benefit of tax shield that arise from the financing of the debt. The application of debt is further supported by the agency theory as advanced by Kraus and Litzenberger (1973), who in explaining tradeoff theory noted that the manner in which companies select the amount of debt and equity funds to be involved in their structure of capital to help strike a balance between the tax benefits and the costs. This balance will lead to an increase in the company's value. Further, it puts an emphasis on the balance between the tax 
shield gains on using debt and the risk of incurring bankruptcy costs. A solemn and important investigation was carried out by Graham (2003) on the available pragmatic literature concerning the effects on the firm's significant value. Further, the bankruptcy cost is often taken as a dead weight that is taken from one shareholder to the other over the stated period. Haugen \& Senbet (1988) discussed this phenomenon in their bankruptcy costs discussion.

Again, any transaction cost form ought to take up a certain analytical status, which is perceived as an important factor when it comes to the funding of the firm's decisions. Ayen \& Orus (2008) state that debt use as the financing source of a firm leads to controlled agency conflicts of interest that further diminish the level of bankruptcy and financial misery that firms may experience in the market. The use of finances obtained from debt by firms help the company to increase its operations. The increase of the operations leads to an optimization of the wealth of the shareholders and the significant value. This study showed the application of the trade-off theory in Kenya as the ratio of debt-equity has an affirmative link to the firms. Therefore, the firm is likely to balance the ideal capital structure through looking for finances from the capital market to fund its operations unlike focusing its efforts on the short-term debt and the bank overdraft (Kibet, et al., 2011).

An economic environment in which firms operate is an important factor that determines how better a firm can perform (Sambasivam \& Ayele, 2013). A significantly positive relation has been found between the capital market growth and the capital structure. Moreover, this has explained how a good environment allows firms to utilize the external sources to fund their projects. This is in line with the findings of (Booth, Aivazian, Kunt, \& Maksimovic, 2001). According to Abor's (2005) study that investigated the debt policy's influence on the firm performance of medium sized businesses, the outcomes pointed that the influence of short-term debt is significant with a negative relationship to returns of the firms in South Africa and Ghana. Additionally, Sambasivam and Ayele (2013) proposed that the growth of the firm, leverage, capital volume and liquidity are the most significant when it comes to the determination of growth and profitability of the firm. They are statistically significant. Further, the related liquidity and leverage ratios have a notable negative effect to the firm's profits. Salim and Yadav (2012) investigated the connection of capital structure to the performance of the firm. They used a sample of 237 firms that are listed in the Malaysia's Bursa Malaysia Stock Exchange.

\section{Methodology}

The research design is the systematic sequence which unifies data to enable investigation of questions of research so as to enable drawing of a conclusion based on data available (Yin, 1994).

3.1: Source of data: The study used a secondary data compared over years and thus time series and crosssectional analysis was possible. Cross-sectional data analysis usually includes data analysis over time like from 2010 to 2014

3.2: Sample size: The study took into consideration all the firms hence it was a census survey which usually takes into consideration all firms especially when they are not many (Saunders, Lewis, \& Thornhill, (2007). The firms that were considered in this study were 36 non-financial companies that are listed at the Nairobi Securities Exchange.

3.3: Data analysis: The study utilized multivariate regression technique, correlation, and point by point insights examinations. The review explored the relationship between the variables and their association with each other. A correlation grid that incorporated the values of correlations coefficients for the variables utilized as a part of the examination. The regression examinations and expressive insights were connected to complete the investigation of the mediating effect of firm growth on the relationship between capital structure, and value of non-financial firms listed at the Nairobi Securities Exchange in Kenya from 2010 to 2014. Multivariate factual examinations were utilized to learn the impact of capital structure and other controllable variables on the value of the firm.

\subsection{Study hypothesis}

H02: There is no significant intervening effect of firm growth on the relationship between capital structure and firm value

\section{Data Analysis And Interpretation}

STATISTICS OF THE VARIABLES

\begin{tabular}{|l|c|c|c|c|c|r|r|}
\hline \multicolumn{1}{|c|}{ Variable } & Obs & Mean & Std. Dev. & Min & Max & \multicolumn{1}{c|}{ SK } & \multicolumn{1}{c|}{ KU } \\
\hline TQ & 180 & 1.6423 & 3.38689 & -0.01912 & 36.8677 & 8.0178 & 76.2470 \\
\hline LTDTA & 180 & 0.24173 & 0.35242 & -0.0005 & 3.1934 & 4.2904 & 31.0246 \\
\hline STDTA & 180 & 0.8167 & 2.2920 & 0.0000 & 21.0841 & 7.80710 & 68.8009 \\
\hline DERatio & 180 & 1.0585 & 2.4353 & -0.0000 & 22.0841 & 7.3615 & 62.7997 \\
\hline RTE & 180 & -0.1066 & 0.8735 & -2.5211 & 6.9275 & 4.1414 & 35.1736 \\
\hline FGRate & 180 & -0.0754 & 0.6797 & -1.0000 & 6.0518 & 3.9544 & 38.8389 \\
\hline RRateInt & 180 & 9.0719 & 2.9587 & 3.8407 & 12.0259 & -0.7788 & 2.2998 \\
\hline RGDP & 180 & 6.0168 & 1.3013 & 4.5549 & 8.4023 & 0.9233 & 2.6228 \\
\hline EXCR & 180 & 0.0468 & 0.0658 & -0.0482 & 0.1217 & -0.0504 & 1.5478 \\
\hline
\end{tabular}


The Mediating Effect of Firm Growth on the Relationship between Capital Structures and Value of ..

Note: TQ: Tobin Q; LTDTA: Long-term Debt to Total Assets; STDTA: Short-term Debt tot Total Assets; DE-Ratio: Debt Equity Ratio; RTE: Retained Earnings; FG-Rate: Firm Growth Rate; RRateInt: Real Rate of Interest; RGDP: Real GDP and EXCR: Exchange Rate.

Obs: Observation; Std. Dev. Standard Deviation; Min: Minimum; Max: Maximum; SK: skewness and KU: kurtosis; * Significant Level at $P \leq 0.05$

In this review, the researcher computed Tobin's $Q$ as a measure of Firm value. The outcomes above show that the normal Tobin Q proportion of all the recorded non-budgetary firms at the Nairobi stock trade was 1.64226 which was more worthy than one demonstrating that organizations were worth more than their market value, the market appeared to exaggerate the prices.

Regression Results on the relationship between Capital structures on firm value (a) Goodness of Fit Results

\begin{tabular}{|c|c|c|c|}
\hline \multicolumn{3}{|c|}{ ANOVA Results } \\
\hline Source & SS & Df & MS \\
\hline Model & 66.0935 & 2 & 33.0468 \\
\hline Residual & 10.0631 & 172 & 0.05851 \\
\hline Total & 76.1566 & 174 & 0.43768 \\
\hline
\end{tabular}

Note: ANOVA: Analysis of Variances; SS: Sum of Squares; DF: Degree of Freedom, MS: Means Square and $*$ Sign. Level $P \leq 0.05$

The explanation of this Table 4.5 (a) is the same as for Table 4.4 (a) because it is the direct relationship between capital structure and firm value, which the first step in stepwise regression analysis as recommended, by Baron and Kenny (1986) for the test of mediation.

Regression Results of Dependent variable (Firm value) with Capital Structure and intervening variable (Firm Growth)

Goodness of Fit Results

\begin{tabular}{|c|c|c|c|}
\hline \multicolumn{4}{|c|}{ ANOVA Results } \\
\hline Source & SS & Df & MS \\
\hline Model & 4.06396 & 1 & 4.06396 \\
\hline Residual & 44.8831 & 178 & 0.25215 \\
\hline Total & 48.9471 & 179 & 0.27345 \\
\hline
\end{tabular}

Note: ANOVA: Analysis of Variances; SS: Sum of Squares; DF: Degree of Freedom, MS: Means Square and $*$ Sign. Level $P \leq 0.05$

There was a significant effect of the joint relationship between capital structure, firm growth, and macroeconomic factors on firm value as indicated by the value of $[\mathrm{F}(1,178, \mathrm{P}=<0.05]$. The $\mathrm{P}$-value $=0.0001$ is significant showing that the joint effect have influence on the firm value of nonfinancial firms listed on the Nairobi Securities Exchange.

(b) Model Summary

Note: * Significant Level P $\leq 0.05$

\begin{tabular}{|l|c|}
\hline \multicolumn{2}{|c|}{ Model Goodness of fit results } \\
\hline R-squared & 0.083 \\
\hline Adj R-squared & 0.0779 \\
\hline
\end{tabular}

The model indicates a statistically significant relationship between firm value and both capital structure and firm growth $[\mathrm{P}=<0.05]$, and the multiple regression models had an adjusted $\mathrm{R} 2=0.0779, \mathrm{~F}[1,178]=16.12$. Capital structure and firm growth of nonfinancial firms accounted for 7.8 percent of the variance in the firm value of listed nonfinancial firms at the Nairobi Securities Exchange.

(c) Regression Coefficients

\begin{tabular}{|c|c|c|c|c|}
\hline \multicolumn{5}{|c|}{ Estimated Model Results } \\
\hline & Coef. & Std. Err. & $\mathbf{t}$ & $\mathbf{P}>\mathbf{t}$ \\
\hline FG Rate & -0.3562 & 0.089 & -4.01 & 0 \\
\hline _cons & 1.5962 & 0.212 & 7.54 & 0 \\
\hline
\end{tabular}

NOTE: * SIGNIFICANT LEVEL P $\leq 0.05)$, COEF: COEFFICIENT; STD. ERR: STANDARD ERROR. 
The Table 4.6 above shows the test of the third step, which involved a simple regression analysis with the mediator/intervening variable. From the regression results, the intervening variable was a significant predictor of the Firm Value $(\beta 1=-0.35621, \mathrm{p}=<0.05)$. Therefore, firm growth does intervene in the relationship between capital structure and firm value as a dependent variable.

\section{Summary of findings}

The intervening variable firm growth also had a positively statistically significant relationship ( $\beta=$ $0.8008, \mathrm{p}$-value $=0.000$ ) with the response variable. There was a negative relationship between firm growth rate and firm value. On average, a unit increase in firm growth measure leads to a 0.356 decrease in average firm value an indication of negative relationship between the two study variables. From these results of this explanatory relationship, it indicates that up to $92 \%$ of average firm value is left to other factors and random variation.

Firm growth in this present study was measured by change in absolute resources proportion over the period. A higher firm growth rate demonstrated an extension in the organization's exercises about deals, benefits and resources and decisively a sign of the more prominent probability of survival. Likewise, firms that experience constant growth have a higher likelihood of getting by in the market.

\section{Conclusion}

The conclusion of the study has explained unmistakably that the theoretical and the findings of this study bolster specialists in the territory of corporate back and financial monetary to evade the disappointment and delisting of the firms from the Nairobi Securities Exchange as it has occurred in the course of recent years with regards to Kenya. The scientists ought to look at the capital structure from the viewpoint of characterizing a key bearing that would help firms and speculators to fitting financing choice. The present writing demonstrated that firms in Kenya financed their investment through here and now obligation. The study additionally looks at the applicable of the impact of firm growth completely as inside factors and lines up with the outer factors (macroeconomic factors) that direct the connection between free factors and the indicator

\section{References}

[1]. J. Abor, The Effect of Capital Structure on Profitability: An Empirical analysis of Listed Firms in Ghana. Journal of Risk Finance, 6 (4), 38-47 (2005).

[2]. M. Ayen, \& E. Oruas, Testing of pecking order theory in ISE (Istanbul stock exchange market). International Research Journal of Finance \& Economics, 21, 19-22. (2008).

[3]. R. Campbell, B. Harveya, \& V.L. Karl, The effect of capital structure when expected agency costs are extreme. Journal of Financial Economics, 74, 3-30. (2004).

[4]. S.C. Myers, The capital structure puzzle. Journal of Finance, 39, 575 - 592 (1984)

[5]. F. Modigliani, \& M..H. Miller, The cost of capital, corporation finance and the theory of investment. American Economic Review, 48 (3), 261-97, (1958).

[6]. M. Murekefu, \& O.P Ouma, The Relationship between Dividend Payout and Firm Performance: A Study of Listed Companies in Kenya. European Scientific Journal, 8 (9), 435-456, (2012).

[7]. N. Mokhova \& M. Zinecker, Macroeconomic factors and corporate capital structure. Journal Procedia - Social and Behavioral Sciences, 110, 530-540, (2014).

[8]. G. Rajan \& L. Zingales, What do we know about capital structure? Some evidence from international data. Journal of Finance, 50, 1421-1460, (1995).

[9]. W.S. Ruan, Managerial Ownership, Capital Structure and Firm Value: Evidence from China's Civilian-run Firms, Australasian Accounting Business and Finance Journal, 5(3), 2011, 73-92, (2011).

[10]. I.M. Pandey, Financial Management (9th revised Edition ed.). India. (2004).

[11]. J.R. Graham, Debt, Leases, Taxes, and the endogeneity of corporate tax status. Journal of Finance, 53 (2003).

[12]. E.K. Laitinen, A Dynamic Performance Measurement System: Evidence from Small Finnish Technology Companies. Scandinavian Journal of Management, 18 (1), 65-69, (2002).

[13]. A.G. Khan, The relationship of capital structure decisions with firm performance: A study of the engineering sector of Pakistan, International Journal of Accounting and Financial Reporting, 2, (1), 245-262, (2012).

[14]. A. Kraus, \& R.H Litzenberger, A state- preference model of optimal financial leverage. The Journal of Finance, 28 (4), 911-922(1973).

[15]. B. Kibet, The Determinants of Leverage at the Nairobi Stock Exchange, Kenya. The Second Asian Business and Management Conference 2011 Osaka. Japan-(2011).

[16]. M. Mansoon \& M. Rauf, Impact of Corporate Governance on Capital Structure - A Study of KSE Listed Firms. Global Management Journal for Academic \& Corporate Studies, 3 (1), 94-110-(2013).

[17]. Y. Sambasivam \& A. Ayele, A study of the performance of insurance companies in Ethiopia. International Journal of Marketing, Financial Service \& Management Research, 2 (7), 138-150- (2013).

[18]. M. Salim \& R. Yadav, Capital Structure and Firm Performance: Evidence from Malaysian Listed Companies, International Books Congress on Interdisciplinary Business and Social Science, 65, 156 - 166, (2012).

[19]. M. Saunders, P. Lewis \& A. Thornhill Saunders. Research Methods for Business Students (5th Edition ed), Pearson Education Ltd, (2007).

[20]. E.T. Penrose, Theory of the Growth of the Firm. New York: Oxford University Press (1959).

[21]. R. Yin, Case study research: Design and methods (2nd ed.). Thousand Oaks, CA: Sage Publishing (1994). 
[22]. S. Akhtar \& B. Oliver, Determinants of Capital Structure for Japanese Multinational and Domestic Corporations. International Review of Finance, 9, 1-26. (2009).

[23]. A.N. Berger \& P.E. Bonaccorsi di, Capital structure and firm performance: a new approach to testing agency theory and an application to the banking industry. Journal of Banking and Finance, 30, 1065 -1102. (2006)

[24]. G. Gopinath, International Prices and Exchange Rates. Handbook of International economics, (2012).

[25]. A.D. Zuraidah, Capital Structure Effect on Firms Performance: Focusing on Consumers and Industrials Sectors on Malaysian Firms International Review of Business Research Papers (2012) 8, (5), 137 - 15

[26]. T.P. Velnampy, Does capital structure cause high firm value? Evidence from selected companies in Colombo stock exchange Sri Lanka: In business and Technology, (2011), 9(3), 575-592.

[27]. R.A. Haugen, \& L.W. Senbet, Corporate Finance and Taxes. A review. Financial Management, (1988). 15, 5-22.

\section{Theses}

[28]. G. Donaldson, Corporate debt capacity: a study of corporate debt policy and the determination of corporate debt capacity. Harvard Graduate School of Business Administration, Division of Research, Harvard University, Boston (1961)., MA.

\section{Proceedings Papers:}

[29]. Odongo K., Thabang, M. M. \& Leonard, M. (2014). Capital structure, profitability and firm value: panel evidence of listed firms in Kenya. Munich Personal RePEc Archive.

[30]. Fama E. \& French, K. (2002). Testing trade-off and pecking order predictions about dividends and debt. Review of Financial Studies, $15,1-33$

Daniel Kon Ater. "The Mediating Effect of Firm Growth on the Relationship between Capital Structures and Value of Nonfinancial Firms listed at the Nairobi Securities Exchange (NSE)." IOSR Journal of Economics and Finance (IOSR-JEF) 8.4 (2017): 41-46. 